\title{
BADANIA NAD TECHNOLOGIĄ OTRZYMYWANIA CIENKICH WARSTW EMITERA METODA ROZPYLANIA MAGNETRONOWEGO DLA ZASTOSOWAŃ W OGNIWACH CIGS
}

\begin{abstract}
Cienkowarstwowe ogniwa fotowoltaiczne wykonane na bazie struktury CIGS (mieszaniny pierwiastków miedzi, indu, galu oraz selenu) należą do II generacji ogniw fotowoltaicznych. Wykazują one efektywność na poziomie zbliżonym do ogniw I generacji, lecz ze względu na niższe zużycie materiału, coraz częściej wypierają z rynku ogniwa krzemowe Artykuł przedstawia rezultaty badań dotyczących sposobu otrzymywania warstwy buforowej CdS (siarczku kadmu), zastosowanej w cienkowarstwowych ogniwach fotowoltaicznych typu CIGS. Przyjęto dwa rozwiązania technologii nanoszenia: warstwa okna CdS uzyskana metodą rozpylenia magnetronowego oraz warstwa okna CdS uzyskana metodą kąpieli chemicznej (CBD- Chemical Bath Deposition). Struktura ta powinna posiadać odpowiednią wielkość przerwy energetycznej, która pozwali na większą absorpcję fotonów, a także wymaga się, aby była cienka (mniej niż $100 \mathrm{~nm}$ ) i jednolita. Warstwy CdS zostały nałożone przez osadzanie w kąpieli chemicznej CBD na szklanych podłożach pokrytych Mo/CIGS (naniesione warstwy metodą sputteringu magnetronowego). Uzyskano dzięki temu warstwę emitera o grubości $80 \mathrm{~nm}$ po czasie osadzania 35 minut. Dla porównania warstwy CdS zostały nałożone poprzez sputtering magnetronowy na podłożu Mo/CIGS, uzyskanym tą samą metodą. Następnie oba rozwiązania zostały przebadane pod względem morfologii powierzchni na elektronowym mikroskopie skaningowym, jak również przeprowadzono analizy składu pierwiastkowego warstw. Zarówno jedna, jak i druga metoda prowadzi do otrzymania warstwy emitera CdS dla zastosowań w ogniwach CIGS.
\end{abstract}

Słowa kluczowe: CIGS, CdS, warstwa buforowa, ogniwa fotowoltaiczne, kąpiel chemiczna CBD, rozpylanie magnetronowe, ogniwa cienkowarstwowe

${ }^{1}$ Autor do korespondencji / corresponding author: Justyna Pietraszek, Politechnika Lubelska, Wydział Inżynierii Środowiska, ul. Nadbystrzycka 40B, 20-618 Lublin, tel. 516169443; justyna.pietraszek@pollub.edu.pl

2 Sławomir Gułkowski, Politechnika Lubelska, Wydział Inżynierii Środowiska, ul. Nadbystrzycka 40B, 20-618 Lublin; tel. (81) 53846 54; s.gulkowski@ pollub.pl 


\section{Wprowadzenie}

Cienkowarstwowe ogniwa fotowoltaiczne na bazie CIGS (mieszaniny miedzi, indu, galu, selenu) posiadają sprawność w skali laboratoryjnej na poziomie ok. 21\%. Schemat tego typu ogniw przedstawia się następująco: elektroda przednia $\mathrm{Al} /$ warstwa $\mathrm{ZnO}$ :Al./warstwa okna CdS/warstwa absorbera CIGS/elektroda tylna $\mathrm{Mo} /$ szkło sodowo-wapniowe SLG. Alternatywnie jako elektrodę przednią ogniwa można zastosować warstwę $\mathrm{SnO}_{2}[1]$.

Warstwą buforową tego ogniwa jest zwykle CdS (siarczek kadmu), uzyskany metodą kąpieli chemicznej CBD - Chemical Bath Deposition, bądź metodą rozpylania magnetronowego (sputtering) [2]. Warstwy buforowe w strukturze ogniwa CIGS posiadają kilka wymogów, które należy wziąć pod uwagę. Jednym $\mathrm{z}$ nich jest fakt, iż warstwa ta powinna mieć przerwę energetyczną o wartości, która pozwoli na większą absorpcję fotonów i zwiększy wydajność [3].

Warstwa CdS na bazie struktury CIGS wykazuje liczne korzystne właściwości, m.in. poprawia ona dopasowanie sieci krystalicznej heterozłącza. Zachowanie dobrej jednorodności tej warstwy może prowadzić do poprawy sprawności ogniw na bazie absorbera CIGS [4]. Innym przykładem struktury cienkowarstwowej wykorzystywanej dla zastosowań w fotowoltaice jest heterostruktura GaAs-Si [5].

\section{Opis procedury badawczej}

Badania dotyczące technologii otrzymywania cienkich warstw emitera metodą rozpylania magnetronowego dla zastosowań w ogniwach CIGS zostały przeprowadzone zgodnie $\mathrm{z}$ harmonogramem:

Etap 1: Przygotowanie i czyszczenie podłoży,

Etap 2: Uzyskanie cienkich warstw absorbera CIGS metodą rozpylania magnetronowego,

Etap 3: Nanoszenie cienkich warstw emitera CdS na podłożach SLG/Mo/CIGS metodą:

- sputteringu magnetronowego,

- kąpieli chemicznej (CBD - Chemical Bath Deposition).

Etap 4: Badanie otrzymanych struktur za pomocą elektronowego mikroskopu skaningowego wraz z analizą składu pierwiastkowego.

\subsection{Przygotowanie i czyszczenie podłoży}

Przed przystąpieniem do procesu rozpylania magnetronowego należy właściwie przygotować i oczyścić próbki, na które nanoszone będą odpowiednie warstwy tworzące strukturę CIGS. Jako podłoże do ogniw zostały wybrane szkiełka mikroskopowe na bazie szkła sodowo-wapniowego (SLG) o wymiarach $76 \times 26 \times 1 \mathrm{~mm}$. Pierwszym etapem przygotowania próbek było docięcie ich do wielkości $15 \times 13 \times 1 \mathrm{~mm}$. 
Kolejnym punktem było oczyszczanie przygotowanych podłoży. Proces mycia wcześniej przyciętego szkła przebiega następująco:

- oczyszczanie przy użyciu acetonu w myjce ultradźwiękowej,

- oczyszczanie przy użyciu etanolu w myjce ultradźwiękowej,

- oczyszczanie przy użyciu wody destylowanej w naczyniu laboratoryjnym, osuszanie przy użyciu azotu.

\subsection{Uzyskanie cienkich warstw absorbera CIGS metodą rozpylania magnetronowego}

Do nanoszenia cienkich warstw metodą rozpylania magnetronowego wykorzystano System AC450 firmy Alliance Concept. System AC450 przeznaczony jest do badań związanych ze osadzaniem rozpylonych atomów, bądź jonów w polu magnetycznym (sputtering magnetronowy). Został on przedstawiony na rysunku 1.

Po odpowiednim przygotowaniu i wyczyszczeniu podłoży zaprogramowano proces osadzania $\mathrm{w}$ systemie AC450, w kolejności zgodnej $\mathrm{z}$ warstwami w strukturze cienkowarstwowej tworzonego ogniwa. Rysunek 2 przedstawia panel sterowania urządzenia firmy Alliance Concept, odpowiedzialny za ustawianie parametrów napylania poszczególnych struktur.

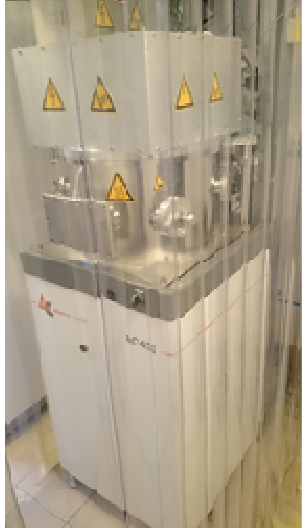

Rys. 1. System AC450 firmy Alliance Concept

Fig. 1. The Alliance Concept system - AC450

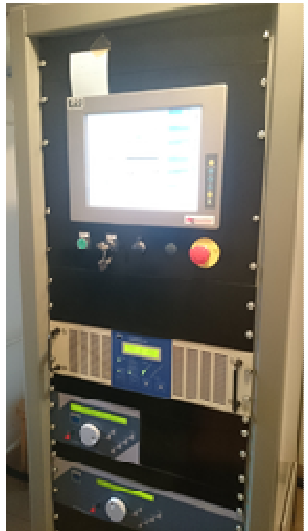

Rys. 2. Panel sterowania systemu AC450 firmy Alliance Concept

Fig. 2. Control panel of Alliance Concept AC450 system

Do badań przygotowano próbki o następującej strukturze: absorber CIGS/elektroda tylna Mo, nanoszone na oczyszczone podłoża ze szkła SLG. Każda z poszczególnych napylanych powłok posiadała odpowiednie parametry ustawione w programie AC450 przedstawione w tabeli 1. 
Tabela 1. Parametry procesu nanoszenia warstwy Mo i CIGS

Table 1. Process parameters of applying layer of Mo and CIGS

\begin{tabular}{|l|l|l|}
\hline Parametry procesu nanoszenia warstwy: & \multicolumn{1}{|c|}{ Warstwa Mo } & \multicolumn{1}{|c|}{ Warstwa CIGS } \\
\hline Ciśnienie początkowe & $1,00 \times 10^{-4} \mathrm{mbar}$ & $9,00 \times 10^{-5} \mathrm{mbar}$ \\
\hline Temperatura & $\mathrm{R} . \mathrm{T}$. & $395^{\circ} \mathrm{C} \pm 15^{\circ} \mathrm{C}$ \\
\hline Moc DC & $120 \mathrm{~W}$ & $80 \mathrm{~W}$ \\
\hline Przepływ gazu Ar & $20 \mathrm{sccm}$ & $20 \mathrm{sccm}$ \\
\hline Czas procesu & $60 \mathrm{~min}$ & $90 \mathrm{~min}$ \\
\hline Ciśnienie podczas procesu & $1,99 \times 10^{-2} \mathrm{mbar}$ & $1,96 \times 10^{-5} \mathrm{mbar}$ \\
\hline
\end{tabular}

\subsection{Nanoszenie cienkich warstw emitera $\mathrm{CdS}$ na podłożach SLG/Mo/CIGS}

Warstwa emitera CdS została nałożona metodą sputteringu magnetronowego na poprzednio przygotowane próbki o następującej strukturze: absorber CIGS/elektroda tylna Mo/SLG. Parametry napylania zostały ustawione w oprogramowaniu magnetronu AC450 i przedstawiono je w tabeli 2.

Tabela 2. Parametry procesu nanoszenia warstwy CdS

Table 2. Process parameters of applying CdS layer

\begin{tabular}{|l|l|}
\hline \multicolumn{1}{|c|}{ Parametry procesu nanoszenia warstwy: } & \multicolumn{1}{|c|}{ Warstwa CdS - Siarczek kadmu } \\
\hline Ciśnienie początkowe & $1,00 \times 10^{-4} \mathrm{mbar}$ \\
\hline Temperatura & $200{ }^{\circ} \mathrm{C} \pm 5^{\circ} \mathrm{C}$ \\
\hline Moc RF & $80 \mathrm{~W}$ \\
\hline Przepływ gazu Ar & $20 \mathrm{sccm}$ \\
\hline Czas procesu & $4 \mathrm{~min} 24 \mathrm{~s}$ \\
\hline Ciśnienie podczas procesu & $2,09 \times 10^{-2} \mathrm{mbar}$ \\
\hline
\end{tabular}

Dla porównania parametrów, warstwa CdS została nałożona przez osadzanie w kąpieli chemicznej na podłożu SLG, bądź dodatkowo na podłożu Mo/CIGS (poprzednio naniesione poprzez rozpylenie magnetronowe). Stanowisko do wykonywania kąpieli chemicznej umieszczone pod wyciągiem, składa się z płyty grzejnej umożliwiającej regulację temperatury oraz zlewki o pojemności $1000 \mathrm{ml}$. Zastosowane jest to w celu utrzymania lepszej równomierności temperatury kąpieli. Aparatura potrzebna do przeprowadzenia doświadczenia została przedstawiona na rysunku 3.

Przy badaniach wykorzystano następujący wariant kąpieli chemicznej [2]:

- $366 \mathrm{ml}$ dejonizowanej wody, $62,5 \mathrm{ml}$ wodorotlenku amonu $\mathrm{NH}_{4} \mathrm{OH}$ (28-30\%), - $50 \mathrm{ml}$ siarczanu kadmu $\left(0,015 \mathrm{M} \mathrm{CdSO}_{4}\right)$,

- $25 \mathrm{ml}$ tiomocznika $\left(1,5 \mathrm{M} \mathrm{NH}_{2} \mathrm{CSNH}_{2}\right)$ w temperaturze $65^{\circ} \mathrm{C}$.

Uzyskano dzięki temu warstwę emitera CdS o grubości $80 \mathrm{~nm}$ po czasie osadzania 35 minut, naniesiona na czyste szkło sodowo-wapniowe (rys. 4). 


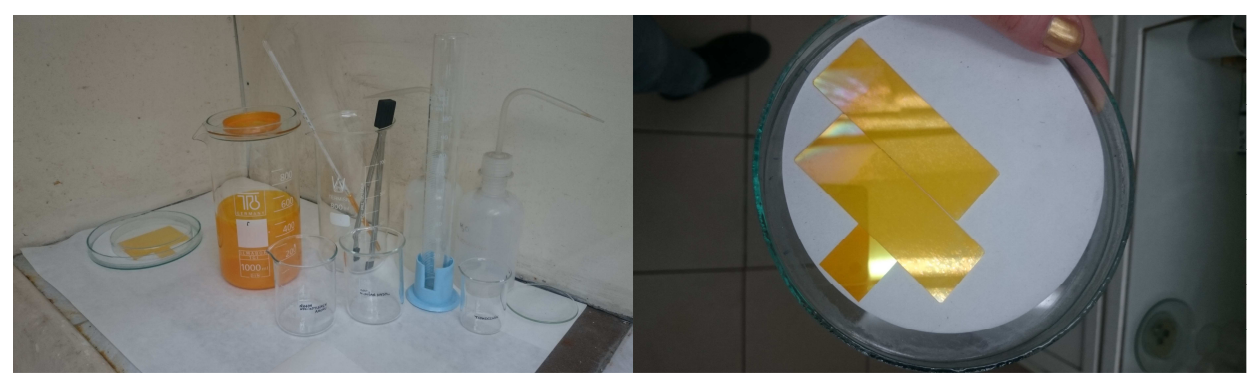

Rys. 3. Kąpiel chemiczna - aparatura

Fig. 3. Equipment of Chemical Bath Deposition

Rys. 4. Warstwa CdS naniesiona metodą kąpieli chemicznej

Fig. 4. CdS layer deposited by $\mathrm{CBD}$

\section{Wyniki badań i ich analiza}

Uzyskane próbki metodą rozpylenia magnetronowego i kąpieli chemicznej zostały zbadane za pomocą elektronowego mikroskopu skaningowego. Przeprowadzono analizę jakościową oraz ilościową ich składu pierwiastkowego. Poniżej przedstawione wyniki morfologii i analizy absorbera CIGS, jak również porównanie morfologii i składu pierwiastkowego warstwy CdS uzyskanej dwiema metodami: rozpylenia magnetronowego i kąpieli chemicznej.

\subsection{Warstwa absorbera CIGS - morfologia i analiza składu pierwiastkowego}

Na rysunku 5 został pokazany obraz powierzchni próbki CIGS. Z wartości składu atomowego przedstawionego w tabeli 3 obliczono stosunek miedzi do indu z galem, galu do indu z galem oraz selenu do indu z miedzią. Wartości tych stosunków powinny zawierać się w przedziałach: $\mathrm{Cu} /(\mathrm{In}+\mathrm{Ga})-0,7 \div 1,0$, $\mathrm{Ga} /(\mathrm{In}+\mathrm{Ga})-<0,3, \mathrm{Se} /(\mathrm{In}+\mathrm{Cu})-<1,0$. Obliczone wartości mieszczą się w przyjętych założeniach. W przypadku $\mathrm{Cu} /(\mathrm{In}+\mathrm{Ga})$ jest to wynik zbliżony, mieszczący się w granicy błędu, spowodowany nierównomiernością powstałego kryształu.

Tabela 3. Analiza składu pierwiastkowego warstwy CIGS

Table 3. Analysis of the elemental composition of the CIGS layer

\begin{tabular}{|c|c|c|c|c|c|c|c|c|}
\hline $\boldsymbol{N}-\boldsymbol{K}$ & $\boldsymbol{O}-\boldsymbol{K}$ & $\boldsymbol{F}-\boldsymbol{K}$ & $\boldsymbol{S}-\boldsymbol{K}$ & $\boldsymbol{C u}-\boldsymbol{K}$ & $\boldsymbol{G a}-\boldsymbol{K}$ & $\boldsymbol{S e}-\boldsymbol{K}$ & $\boldsymbol{M o}-\boldsymbol{L}$ & $\boldsymbol{I n}-\boldsymbol{L}$ \\
\hline 0.00 & 14.85 & 4.02 & 0.00 & 18.34 & 6.18 & 33.73 & 0.80 & 22.08 \\
\hline
\end{tabular}

Obliczenia:

$\mathrm{Cu} /(\mathrm{In}+\mathrm{Ga})=18.34 /(22.08+6.18)=0.64$

$\mathrm{Ga} /(\mathrm{In}+\mathrm{Ga})=6.18 /(22.08+6.18)=0.21$

$\mathrm{Se} /(\mathrm{In}+\mathrm{Cu})=33.73 /(22.08+18.34)=0.84$ 


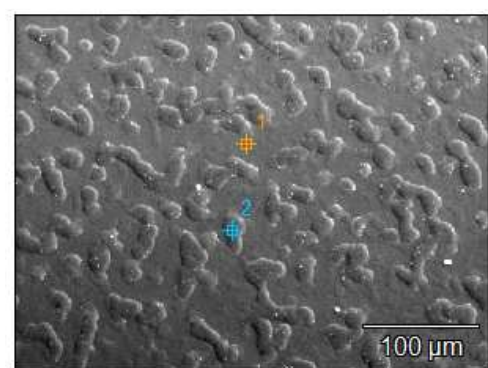

Rys. 5. Morfologia warstwy CIGS

Fig. 5. The morphology of the CIGS layer

\subsection{Warstwa okna CdS - porównanie morfologii i analiza składu pierwiastkowego dla metody sputteringu magnetronowego i kąpieli chemicznej}

Na rysunku 6 przedstawiono obraz powierzchni warstwy emitera CdS naniesionej metodą sputteringu magnetronowego na podłożu SLG/Mo/CIGS, natomiast rysunek 7 przedstawia obraz powierzchni warstwy emitera CdS naniesioną metodą kąpieli chemicznej CBD. Morfologie tych próbek są bardzo zbliżone do siebie.

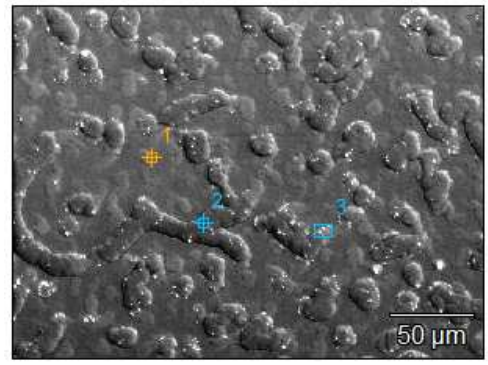

Rys. 6. Morfologia warstwy CdS rozpylanie magnetronowy

Fig. 6. The morphology of the CdS layer - magnetron sputtering

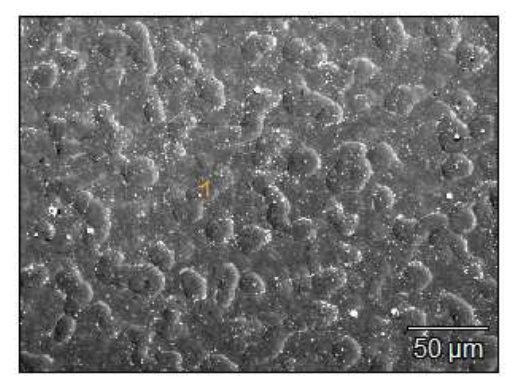

Rys. 7. Morfologia warstwy CdS kąpiel chemiczna

Fig. 7. The morphology of the CdS layer - chemical bath deposition

Rysunki 8 i 9 prezentują analizy jakościowe i ilościowe składu chemicznego warstwy CdS uzyskanej odpowiednio poprzez napylanie magnetronowe oraz kąpiel chemiczną. Wysokość pików na wykresie określa ilość danego pierwiastka obecnego w badanej warstwie. 


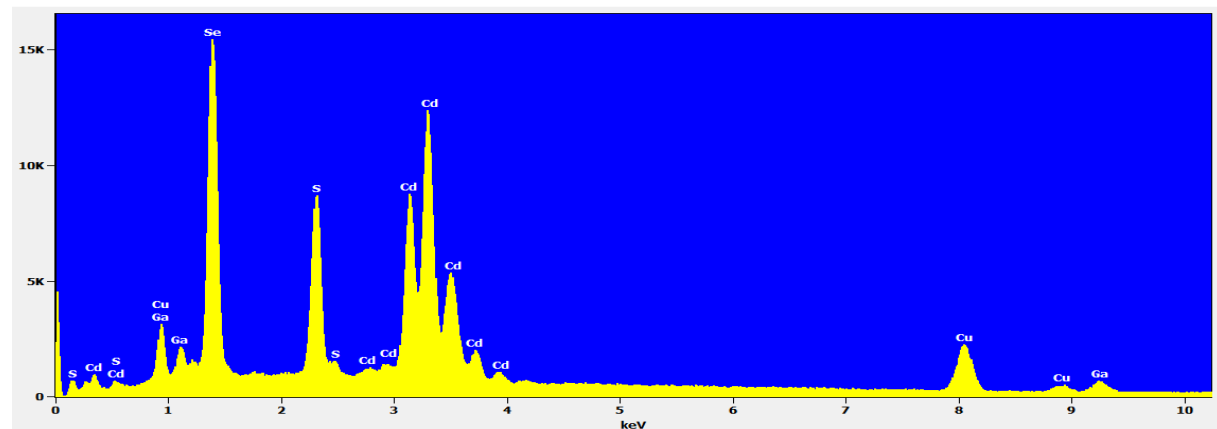

Rys. 8. Widmo EDS dla warstwy CdS - rozpylanie magnetronowe

Fig. 8. EDS spectrum for the CIGS layer - magnetron sputtering

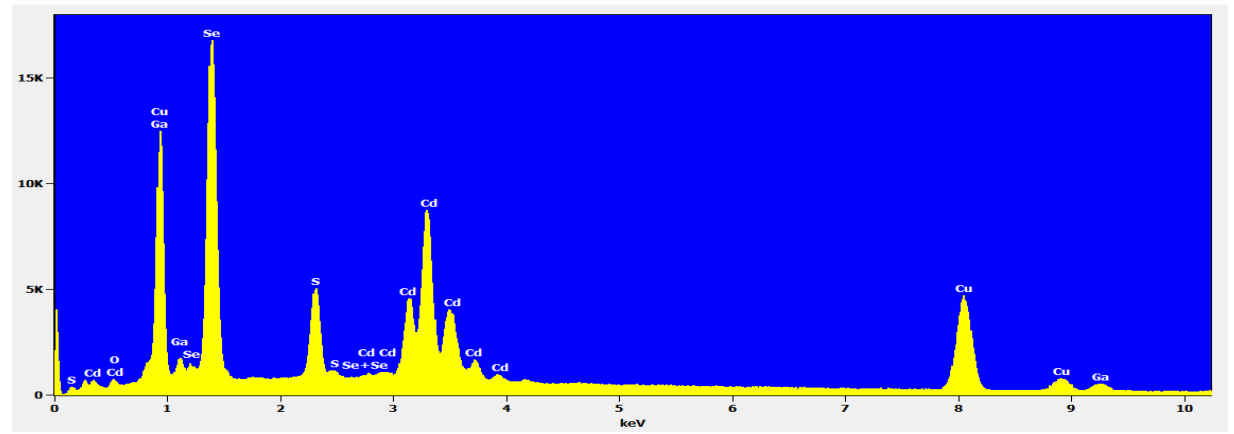

Rys. 9. Widmo EDS dla warstwy CdS - kąpiel chemiczna

Fig. 9. EDS spectrum for the CIGS layer - chemical bath deposition

\section{Wnioski}

Porównano dwie metody nanoszenie cienkich warstw emitera $\mathrm{CdS}$ na podłożach SLG/Mo/CIGS: sputtering magnetronowy oraz kąpiel chemiczna. Analiza jakościowa i ilościowa składu chemicznego warstwy CdS uzyskana metodą rozpylania magnetronowego, jak również naniesiona metodą $\mathrm{CBD}$ wykazała obecność kadmu i siarki, co oznacza, że zastosowanie obydwu metod prowadzi do osadzenia się tych pierwiastków na podłożach. Obie metody prowadzą do otrzymania warstwy emitera CdS dla zastosowań w ogniwach CIGS.

\section{Literatura}

[1] Grudniewski T., Lubańska Z., Czernik S.: Charakterystyka AFM cienkich warstw $\mathrm{SnO} 2$ uzyskanych podczas sputteringu magnetronowego przy wybranych warunkach procesu. Czasopismo Inżynierii Lądowej, Środowiska i Architektury - Journal of Civil Engineering, Environment and Architecture, JCEEA, t. XXXII, z. 62 (2/15), 2016, s. 99-106, DOI:10.7862/rb.2015.40. 
[2] Alexander J.N., Higashiya S., Caskey Jr D., Efstathiadis H., Haldar P.: Deposition and characterization of cadmium sulfide (CdS) by chemical bath deposition using an alternative chemistry cadmium precursor, Elsevier, Solar Energy Materials \& Solar Cells 125, 2014, pp. 47-53.

[3] Gułkowski S., Krawczak E., Olchowik J. M.: Optimization of metallic precursor thickness ratio for CIGS solar cell prepared by magnetron sputtering process, 31st European Photovoltaic Solar Energy Conference and Exhibition, 2015, pp. 1330-1332.

[4] Acciarri M., Le Donne A., Garattini P., Falcone M., Marchionna S., Meschia M., Moneta R., Gasparotto A.: $\mathrm{Cu}(\mathrm{In}, \mathrm{Ga}) \mathrm{Se}_{2}$ solar cells on flexible substrate fabricated by an innovative roll to roll hybrid sputtering and evaporation process, 29th European Photovoltaic Solar Energy Conference and Exhibition, 2014, pp. 1837-1839.

[5] Zdyb A., Olchowik J. M., Szymczuk D., Mucha J, Zabielski K., Mucha M., Sadowski W.: Analysis of the Interfacial Energy of GaAs-Si Heterostructures”, Cryst. Res. Technol. 37 (2002), p. 875-880.

\title{
RESEARCH ON THE TECHNOLOGY OF OBTAINING THIN LAYERS OF EMITTER IN CIGS PHOTOVOLTAIC CELLS BY USING MAGNETRON SPUTTERING PROCESS
}

\begin{abstract}
S u m m a r y
Thin-film photovoltaic cells created based on the structure of CIGS (a mixture of the elements copper, indium, gallium and selenium) belong to the second generation of photovoltaic cells. They show the effectiveness of a level similar to the cells of the first generation, but due to lower material consumption, they increasingly forcing out silicon solar cells. The article presents the results of research of the method for obtaining a CdS buffer layer, used in thin-film CIGS photovoltaic cells. Two technology solutions of application were adopted: layer of CdS window obtained by the magnetron sputtering and layer of CdS obtained by chemical method (CBD- Chemical Bath Deposition). CdS layer has been imposed by the deposition in the chemical bath on glass substrates covered with Mo/CIGS (layers applied by magnetron sputtering). Allowing an emitter layer having a thickness of $80 \mathrm{~cm}$ after 35 minutes of deposition time. For comparison, a CdS layer was applied by magnetron sputtering on the substrate Mo/CIGS obtained by the same method. Subsequently, both solutions were examined in the SEM microscope to check the surface morphology, and also to analysis the elemental composition of the layers. Both methods leads to receive CdS emitter layer for use in CIGS cells.
\end{abstract}

Keywords: CIGS, CdS buffer layer, photovoltaic cells, chemical bath deposition CBD, magnetron sputtering, thin-film cells

Przestano do redakcji: 29.01.2017 r.

Przyjęto do druku: 31.03.2017 r. 